\title{
SURVEY
}

\section{Labour Studies and Labour History in South Africa: Perspectives from the Apartheid Era and After}

\author{
B IL L FREUND \\ School of Social Sciences, University of KwaZulu-Natal \\ Durban 404I, South Africa
}

E-mail: william.m.freund@gmail.com

\begin{abstract}
AвSTRAст: This article attempts to introduce readers to the impressive and influential historical and contemporary literature on South African labour. A literature with some earlier antecedents effectively applied classic sociological and historical themes to the specific conditions of South African political and economic development. Research on the phase of politicized and militant white worker action ties up with research into the international pre-World War I labour movement. The strength of this literature reflected the insurgent labour movement linked to political struggle against apartheid before I990. After this review, the second half of the paper tries to consider and contextualize the challenging post-apartheid labour situation together with its political aspects. With the successful conclusion of the anti-apartheid struggle, students of the labour movement, as well as of South African society, have become more aware of the distance between establishing a liberal democracy and actually changing society itself in a direction leading towards less inequality and an improved life for those at the bottom of society, or even the broad mass of the population. As recent literature reveals, the development of post-apartheid South Africa has been a differential and problematic experience for labour.
\end{abstract}

\section{INTRODUCTION}

The body of literature studying labour in South Africa and specifically labour history is very substantial and deserving of international attention. The relationship of the two requires some explanation, however. The study of modern South African history in the last thirty to forty years has justifiably impressed readers with other backgrounds and interests. However, it has never enjoyed the same prestige or appeal at home. Within South Africa, history as an academic discipline does not attract many practitioners or students, especially as it has become a relatively 
rare choice for secondary school requirements. The most popular social science subject is probably sociology, vying with psychology. Much labour history tends to form therefore a part of broader labour studies rather than to be situated within, say, a general social or economic history. It has therefore the advantages and disadvantages, methodological included, that come from being tied to politics and tied to the present. I try here to pinpoint major studies that fall outside this discourse but they are relatively exceptional. The first part of this paper tries generally to review some of the highlights of the older labour literature.

Until the political turning point of I994, these studies might be said to have two emphases: first, the assumption that the entire system of power in society hinged on the differential exploitation of labour, often focusing on compulsory labour systems that created wealth but did not fit the conventional market theories of labour under capitalism. These include the slave system of the old Cape Colony, the indentured labour system of Natal, and the unequal and oppressive "semi-feudal" regimes that prevailed on privately owned farms. Particular attention was given to the history of the massive mine labour force. In general, the "mineral revolution" is given pride of place in explaining the accumulation of capital in South Africa and its consequences.

Second, there was a general assumption that resistance to the system was often and significantly tied to the ability of labour to organize and to form unions. The organizational history of labour became a salient topic in antiapartheid literature, academic and otherwise, from 1960 and eventually extended itself in fine detail by region, time period, and community. Some of this literature could be accused of a kind of immanent triumphalism, assuming that the substitution of oppressive labour forms with more beneficent capitalist or socialist ones would manifest themselves at the time of liberation. It might also be said that the relationship of organization to the broad context of work, as opposed to the more obviously relevant kinds of wage labour, was not often explored closely.

The dominant group with the right to political participation in the preI990 dispensation were those defined as whites, the descendants essentially of European settlers in South Africa, although if we apply this terminology to the entire Union/Republic period (1910-1994), this would have to be qualified in various, ultimately minor, ways. Settler descendants sought an exclusive racially bounded society, but economic developments over time led to the incorporation of not merely large numbers of free and unfree labourers of colour but also of a conquered indigenous African population into the workforce. These became demographically the large (and growing) majority. The idea that whites were the logical superior bearers of modern culture and science was an internationally widely accepted one, completely legitimate when the Union of South Africa was formed in I9I0, but by the time the Republic was proclaimed in I960 the moral power of decolonization had triumphed as international discourse and the old racial system had 
become unacceptable. In South Africa itself, liberal and radical intellectuals denounced an unjust and unsustainable political system.

Labour, citizenship, and society were linked in complex ways that reflected a long historical development for the exploitation of black labour. A white working class that was "bounded" profited from this system, rather like the classic assessments of worker aristocracies of Lenin and Luxemburg (used to help explain the collusion of worker organizations in policies of imperialism and war in the West), while the poorly paid workers of colour provided the core of profitable value.

Black workers in the gold mines, the major source of export earnings over decades, numbered in the hundreds of thousands (albeit the majority came from beyond South Africa's national borders), dependent on massive control systems on contracts, at the end of which they would eventually return to subsistence level farms looked after by wives and children. Whether foreign or South African, opponents of what the government called the apartheid, or separate development system, saw the exposition of labour conditions and how they developed as the most crucial route to understanding how society worked. Moreover, in the potential of labour - black labour - to organize and to resist seemed to lie much of the hope for eventual transformation or revolution. As such, the history of labour organization, the racial element in a divided working class, the political links of pioneering trade unions, offered a potentially impressive guide to resistance and change.

\section{THE DEVELOPMENT OF SOUTH AFRICAN LABOUR HISTORY}

Both of the best-known South African academics affiliated (at least for important periods) with the Communist Party of South Africa after World War II, Jack Simons, specialist in African society and the scientist Edward Roux, produced long, detailed studies encapsulating the history of resistance in which labour organization and labour resistance was entwined. Roux's Time Longer than Rope: A History of the Black Man's Struggle for Freedom in South Africa was first published in 1948, although it only became widely known when republished by an American university press in the I960s. ${ }^{2}$ It was a mix of professional and amateur history writing by an ex-communist who was still committed to the struggle. Simons's book, Class and Colour in South Africa I850-1950, came out twenty years later, although it was long in the making, at a time when he was already in exile, and it was co-authored by his wife Ray

I. Stanley Greenberg, Race and Class in Comparative Development: South Africa in Comparative Perspective (Johannesburg, 1980).

2. Edward Roux, Time Longer than Rope: A History of the Black Man's Struggle for Freedom in South Africa (Madison, WI, 1964). 
Alexander who had been a prominent trade unionist herself. ${ }^{3}$ These books idealized the creation of an inclusive democracy in South Africa, and assumed a long-term struggle in which the national question and the labour question were very closely related. It was thus assumed that a struggle focused on mobilizing black politics that would end racial exclusion in South Africa sought to achieve a modern and democratic society which could then give way to a further movement directly aiming at socialism. A later volume by a black exile in the USA demonstrates synthetically the idea that the fight against apartheid was really a fight against the South African version of capitalism. ${ }^{4}$

One should also mention the work of yet another communist exile, Harold Wolpe who, one might argue, has been the most influential and important South African sociologist. Wolpe argued that the whole apartheid project, so-called separate development, was aimed at vainly propping up the "homelands" where a large part of the African population lived, while starting to extrude Africans, including African workers, out of the cities where economic development had inevitably attracted or pushed them. Black urbanization had become a powerfully noticeable social trend by the start of the 1940s. Wolpe also foreshadowed the separate development project as Sisyphean. ${ }^{5}$ Here Wolpe tied the main thrust of politics not with the drive to modernize society but in response to the very labour-force contradictions that had been engendered by the dominant social form of industrialization. By the time the National Party took office in 1948, liberal bureaucrats, academics, and activists were already asking - in vain - for black urbanization to be acknowledged and accommodated, and black leadership, almost across the spectrum, called for a diminution, if not destruction, of the constraints placed on the movement of black workers. Wolpe thus tied labour laws and practices to the whole hegemonic project of white rule.

It can be argued that these seminal books set the tone for a rather far-ranging and detailed literature that took off from the late i 960 on onwards and flourished especially in the I970s and I980s. There are, however, two major ingredients to be added. First, at exactly this time, black labour did become more restive in South Africa and succeeded in establishing a new generation of insurgent unions. Intellectuals were attracted to the task of building the new unions and were in fact instrumental in their generation. The voice of the so-called independent unions was the South African Labour Bulletin, still in existence. Early Bulletins, apart from intense strategic debates, contained many features on labour history that often look

3. Jack and Ray Simons, Class and Colour in South Africa I850-1950 (London, 1983).

4. Bernard Magubane, The Political Economy of Race and Class in South Africa (New York, 1979).

5. Harold Wolpe, "Capitalism and Cheap Labour in South Africa: From Segregation to Apartheid", in idem (ed.), The Articulation of Modes of Production (London, I972), pp. 289-323. 
surprisingly academic. Their salience for a trade-union audience was just assumed by authors and editors.

Secondly, some South Africans began to experience the influence of left-wing intellectuals moving out of the communist parties and beginning to construct labour history independent of party history and even of trade-union history. This, of course, made possible asking new questions and seeing labour issues from new angles. An influential role here was played by one of the very rare white Trotskyists exiled to Britain, Baruch Hirson. Yours for the Union: Class and Community Struggles 1930-1947 was only published in 1989 but Hirson by then had established an important influence on South Africans exiled to, or passing through, Britain. ${ }^{6}$ The impact of discourses current on the British Left in the 1960 s and I 970 (i.e. pre-Thatcher) was very significant; South Africa had a very large presence in British ideas about the world in this period and the quality British press closely followed events there.

In terms of constructing an actual labour history, Charles van Onselen, perhaps the most important living South African historian, was simultaneously involved in creating a space for understanding both worker control and working-class initiative in his work, first a book on the gold mines of neighbouring Southern Rhodesia (originally an Oxford University thesis), and second a series of essays on life in early Johannesburg, the city built around the reef with a deep seam of gold underneath. ${ }^{7}$ Van Onselen's approach also contained a strong sense of the almost unshakeable power of money - often brutal - to adjust and stay in control, rather than faith in a dedicated revolutionary party. These aspects of his work particularly appealed to white opponents of the regime and exiles who felt relatively impotent as actors in the exiled African National Congress (if they worked within it at all) which came back from a phase of weakness to achieve virtual hegemony as a political resistance movement from the late I970s.

The consequent rich variety of historical and contemporary writing that played on the dominant politics of the ANC but often from an unacceptably independent perspective, was critical both of communism as a political movement from Marxist perspectives and of the black nationalism which flourished just below the surface in the organization. As a result, it has been a literature that has held relatively limited local appeal in South Africa: it disturbs the dominant liberal or conservative mindset of the great majority of whites, while it appears to undermine the line of the post-apartheid dominant party. However, it is also work that

6. Baruch Hirson, Yours for the Union: Class and Community Struggles in South Africa 1930-47 (London [etc.], 1989).

7. Charles van Onselen, Chibaro: African Mine Labour in Southern Rhodesia 1900-1930 (London, 1976); idem, Studies in the Social and Economic History of the Witwatersrand i886-1914, New Babylon, New Nineveh (Cape Town, 1982). 
has inspired quite a number of mainly English-speaking foreigners, some of them quite influential in the making of this school of writing, and also influenced by both radical sociological thinking and the rise of social (but only later, cultural) history.

It is not really possible to cover comprehensively the output of this school of history, but it seems useful at least to mention some of the best-known works to get a sense of its range. Obviously, the gold mines attracted very considerable attention. Parallel to the work of Van Onselen at Oxford, a Canadian, Frederick Johnstone, inserted a historical and sociological assessment of the gold mines in a classic study, Class, Race and Gold. Johnstone's subtle assessment of structural forces guiding a divided labour force was an advance on one of the few entries of South African liberals, Francis Wilson, into the labour field, which saw the constraints on black labour as largely the fault of white labour. ${ }^{8}$ A South African sociologist working in the USA, Dunbar Moodie, very considerably extended this history according to the second line of development by questioning the centrality of party and union to the great gold miners' strike of $1946 .^{9} \mathrm{He}$ went on to explore the cultural and even the sex life of the miners. ${ }^{10}$ The political economy of labour recruitment was extensively covered by a Canadian team, ${ }^{\mathrm{II}}$ while Patrick Harries tried simultaneously to consider the lives of gold mine workers at the mineshaft and at home in rural Mozambique. ${ }^{\mathrm{I} 2}$

In one research area, South African scholarship linked up with established and intensively covered international work. This focused on the radical phase of white-worker action and its place in broader South African labour studies. Three intertwined factors were inherent in this story: first, the circumstances of vulnerability felt by white immigrant workers, primarily attracted to the gold mines of the Witwatersrand in the first quarter of the twentieth century, who faced expensive living conditions in a raw new urban environment; the dangerous and unhealthy work circumstances of the deep-level mines

8. Francis Wilson, Labour in the South African Gold Mines (Cambridge, 1972); Frederick Johnstone, Class, Race, and Gold: A Study of Class Relations and Racial Discrimination in South Africa (London, 1976). One could also compare Johnstone with the massive 3-volume narrative history of gold-mine labour by a veteran of the British trade-union movement, Victor Allen. This adheres as closely as it can to manifesting solidarity towards the National Union of Mineworkers while also revealing the importance and sense of engagement most of the British (far) Left have felt for South African politics. See Victor Allen, The History of Black Mineworkers in South Africa (Keighley, 1993-2002).

9. Dunbar Moodie, "The Moral Economy of the Gold Miners' Strike of 1946", Journal of Southern African Studies, I 3 (1989), pp. I-35.

ı. Idem with Vivian Ndatshe, Going for Gold: Men, Mines and Migration (Berkeley, CA [etc.], 1994).

I I. Jonathan Crush, South Africa's Labor Empire: A History of Black Migrancy to the Gold Mines (Boulder, CO [etc.], I99I).

I 2. Patrick Harries, Work, Culture and Identity; Migrant Labourers in Mozambique and South Africa (Johannesburg [etc.], I99I). 
(eventually the deepest in the world); and a sense of social vulnerability squeezed between the pressures of the financially driven mine managers and the competition, still largely potential, of armies of much more poorly paid black migrant workers which management held over them as a potential threat that could drag their wages down further. Frederick Johnstone called this "structural insecurity", and it particularly affected workers with limited skills or qualifications. ${ }^{\mathrm{I}}$

This is the context that led to several major strikes, including the victorious General Strike of 1913 and finally the Rand Revolt of 1922, suppressed in blood, which attracted other white workers outside the mine premises and seemed to portend a major political intervention. ${ }^{\mathrm{I}}{ }^{4}$ Secondly, out of this milieu or passing through it, were individuals such as the pioneer British Labour MP, Keir Hardie, and militant groups who participated in the insurrectionary and potentially revolutionary circles that were found globally at that time. These sustained anarchist, syndicalist, and socialist influences such as the International Workers of the World, better-known in their American incarnation. Third, there is the question of links to the emergence of the Communist Party of South Africa as other radical groupings largely disappeared from the early i 920 , and to the emergence of trade-union activity responding to and building organization amongst black workers already engaged in significant strikes. This required a break with the mass of white workers who tended

I3. Johnstone, Class, Race and Gold; Greenberg, Race and Class in Capitalist Development. Greenberg is one of a number of important American writers who have been fascinated by the comparison between race-cum-labour relations in the USA and South Africa, a genre that continues. Thus, see also George Frederickson, White Supremacy; A Comparative Study in American and South African History (New York, I98 I); Rick Halpern (ed.), Racializing Class, Classifying Race: Labour and Difference in Britain, the USA, and Africa (New York, 2000); Alex Lichtenstein, “The Hope for White and Black?': Race, Labour and the State in South Africa and the United States, 1924-1956", Journal of Southern African Studies, 30 (2004), pp. I33-155. These are insightful works that make some important historic points. However, the differences between the American and South African situations are structurally more important than the similarities. The differential between black and white in South Africa, especially in the twentieth century, has always been very much more dramatic in every sense: skill, culture, and politics, as well as income. In the USA, the struggle to bring workers together of different backgrounds, racial included, has been central and not without successes. In South Africa, the differences have remained enormous until recently, and even today are largely qualified through the absorption of some workers of colour into jobs and communities with far more resources and opportunities than the majority of the low-skilled, largely black workforce closely aligned to the mass of the black unemployed. Reference can also be made to Safundi: Journal of Comparative American and South African Studies, published in Pretoria. There ought to be more studies that make comparisons with Latin American and other societies, but for an exception, see Allison Drew, "Bolshevizing Communist Parties: The Algerian and South African Experiences", International Review of Social History, 48 (2003), pp. 167-202.

14. Elaine Katz, A Trade Union Aristocracy: A History of White Workers on the Rand and the General Strike of 1913 (Johannesburg, 1976). 
to support the Labour Party or, if they were Afrikaners, the National Party of General Hertzog.

A sociological assessment which considered how and why the separate struggles of white workers, especially in the mines, led them towards helping to cement an attempted racial hegemony, was produced by the current Minister of Trade and Industry, Rob Davies, in his days as a student in Britain. Only late in the day did an historian attack the most dramatic episode of white labour militancy, the 1922 Rand Revolt, ${ }^{\text {Is }}$ but Davies's contemporary, the South African David Yudelman, convincingly explained the way that white labour was incorporated into the ruling bloc in the I920s in a thesis completed in the USA. ${ }^{16}$ After the Pact government including the Labour Party came into power in 1924, there were no more white-worker insurrections. It did remain true that more skilled workers tended to take a more pragmatic and complex attitude to the issues of race and competition. English Marxist Jon Lewis took this story up institutionally from the history of a trade-union federation, as did Eddie Webster (Cast in a Racial Mould, concerning white and black metal workers). ${ }^{17}$ Webster is an Oxford-trained historian-turned-sociologist who founded the very important Sociology of Work Programme at the University of the Witwatersrand which stimulated and trained many younger scholars.

This is a literature that has continued to develop independent of other trends and focused on the two remaining trends as well. More recently, Jon Hyslop has defined an imperial white-labour consciousness - white labourism - that managed to combine militancy vis-à-vis capital with the defence of a racially bounded working class, a convincing concept to which other writers are consistently returning. ${ }^{18}$ While this captures the main outline of social forces at play, it is notable that a recent major history of the Rand Revolt puts its emphasis on violence on the part of the strikers towards the non-striking and even casual black workers and residents. ${ }^{19}$ There has been a distinct interest in the second theme as well: the formal insistence of some socialists in maintaining a principled and internationally derived (but sometimes framed in a paternalistic discourse)

I 5. Jeremy Krikler, White Rising: The 1922 Insurrection and Racial Killing in South Africa (Manchester, 2005).

16. David Yudelman, The Emergence of Modern South Africa: State, Capital and the Incorporation of Organized Labour on the South African Gold Fields 1902-39 (Cape Town, 1982). 17. Jon Lewis, Industrialisation and Trade Union Organisation in South Africa: The Rise and Fall of the South African Trades and Labour Council 1924-55 (Cambridge, 1984); Eddie Webster, Cast in a Racial Mould: Labour Process and Trade Unions in the Foundries (Johannesburg, 1985 ).

I8. Jon Hyslop, "The Imperial Working Class Makes Itself 'White", Journal of Historical Sociology, I 2 (1999), pp. 398-42 I; idem, "Scottish Labour, Race and Southern African Empire: A Reply to Kenefick", International Review of Social History, 55 (2010), pp. 63-81.

19. Krikler, White Rising. 
idea of an inclusive working class, ${ }^{20}$ notably the forthright Keir Hardie, something that led to obvious contradictions when seen with hindsight. Thirdly and finally, others have spotlighted the practical activities of the handfuls of white activists, prodded very firmly by the Comintern in the I 920 s in the case of the communists, to start actively organizing blacks as a critical part of the working class.

Recent studies of three such radical pioneers, David Ivon Jones, Sydney Bunting, and James Bain, who gradually make this transition out of white labourism, are notable, while Lucien van der Walt has been particularly important in recovering the activities of early syndicalists and anarchists, and Allison Drew is particularly committed to resuscitating this early Left historical phase and the first communists. ${ }^{21}$ However, it is interesting to note the continuities: key figures in radical African studies from the I970s were already exploring this terrain. ${ }^{22}$

To understand how racism impacted on late nineteenth-century social patterns where society was at first not so sharply divided, one can refer outside this school to the work of yet another Englishman, Vivian BickfordSmith on Cape Town, and for a study of the growing division of the labour force and the experiences of workers at the dawn of industrial South Africa in the diamond mines of late nineteenth-century Kimberley, to that of Robert Turrell. ${ }^{23}$ These studies effectively consider the antecedents of what Hyslop has systematically explored.

20. William Kenefick, "Confronting White Labourism: Socialism, Syndicalism, and the Role of the Scottish Radical Left before 1914”, International Review of Social History, 55 (2010), pp. 29-62. 2 I. Gwyn Williams and Baruch Hirson, The Delegate for Africa: David Ivon Jones I 883-1924, (London, 1995); Allison Drew, Between Empire and Revolution: A Life of Sydney Bunting (Pretoria, 2007); Jon Hyslop, The Notorious Syndicalist J.T. Bain: A Scottish Rebel in the Colonial South (Johannesburg, 2004); Lucien van der Walt, "Bakunin's Heirs in South Africa? Class and Revolutionary Socialism in South Africa from the IWW to the International Socialist League I910-21", Politikon, 30 (2004) pp. 67-89; idem, "The First Globalisation and Transnational Labour Activism in Southern Africa: White Labourism, the IWW, and the ICU, 1904-1934", African Studies, 66 (2007), pp. 223-25 I; Allison Drew, Discordant Comrades: Identities and Loyalties on the South African Left (Aldershot, 2000); idem, South Africa's Radical Tradition: A Documentary History, I (Cape Town, 1996).

22. Sheridan Johns, "The Birth of the Communist Party of South Africa", International Journal of African Historical Studies, 9 (1976), pp. 371-400; F.S. Johnstone, "The IWA on the Rand", in Belinda Bozzoli (ed.), Labour, Townships and Protest: Studies in the Social History of the Witwatersrand (Johannesburg, 1979), pp. 248-272; Robin Cohen, Introduction and Notes to Albert Nzula, I.I. Potekhin, and A. Zusmanovitch, Forced Labour in Colonial Africa, originally publ. in Russian in 1933 (London, 1979). Nzula was one of the early batch of black recruits to the CPSA; he died in Moscow. The history of the early Left, with an emphasis on the unions, occupies many pages in the work of Roux and Jack and Ray Simons, and also interested a key pioneer of the later historiography, Martin Legassick, recapitulated in Towards Socialist Democracy (Pietermaritzburg, 2007), ch. 5 .

23. Robert Turrell, Capital and Labour on the Kimberley Diamond Fields I871-90 (Cambridge, 1987); Vivian Bickford-Smith, Ethnic Pride and Racial Prejudice in Victorian Cape Town (Cambridge, 1995). 
Other scholars took matters further back. The world of the slaves and the consequences of its abolition have been taken much further in, for instance, the work of Robert Ross, Nigel Worden, Robert Shell, Mary Rayner, John Mason, and Wayne Dooling - all of them very conscious of understanding slaves as workers. ${ }^{24}$ The slave-master relationship and the slaves' lives probably mark out the outstanding area of pre-capitalist labour history developed in South Africa today.

The effort of Solly Sachs, a sometime communist trade unionist, to bring Afrikaner women in the garment industry after World War I into a radicalized and non-racial trade union, has attracted a number of significant scholars, notably the Afrikaner feminist Elsabe Brink; Leslie Witz, who wrote about Sachs's politics wryly and effectively; and most comprehensively, an American from a feminist and socialist background, Iris Berger, who took the story further into the era of Ray Alexander Simons and beyond in Threads of Solidarity: Women in South African Industry $1900-1980 .{ }^{25}$

By the early twentieth century, whether or not tied to any trade-union activity, black workers were beginning to resist the labour system that existed in various forms, including in the mines. The first major episode of black union organization associated with the Industrial and Commercial Workers' Union in the I920s was the subject of a somewhat censorious article from a strong supporter of the independent unions, Phil Bonner, of the University of the Witwatersrand, in a unique publishing event - the first South African published collection of chapters on labour history. ${ }^{26}$ The ICU also attracted an historian in Helen Bradford who saw the importance of the organization in terms of its previously little-known exploits of reaching out to rural workers. ${ }^{27}$ The sense of black workers up against it in agriculture, mining, and the economy as a whole in the $1920 \mathrm{~s}$

24. Robert Ross, Cape of Torments: Slavery and Resistance in South Africa (Boston, MA [etc.], 1983); Nigel Worden, Slavery in Dutch South Africa (Cambridge, I985); Mary Rayner, "Wine and Slaves: Failure of an Export Economy and the Ending of Slavery in the Cape Colony I 806-34" (Ph.D thesis, Duke University, NC, 1986); Robert Shell, Children of Bondage: A Social History of Slave Society at the Cape of Good Hope, 1652-I838 (Johannesburg, I994); John Mason, Social Death and Resurrection (Charlottesville, VA, 2003); and Wayne Dooling, Slavery, Emancipation and Colonial Rule (Pietermaritzburg, 2007).

25. Elsabe Brink, “Maar 'n Klomp Factory Meide': Afrikaner Family and Community on the Witwatersrand during the I920s", in Belinda Bozzoli (ed.), Class, Community and Conflict: South African Perspectives (Johannesburg, 1987), pp. 26I-29I; Leslie Witz, "Servant of the Workers: Solly Sachs and the Garment Workers' Union” (M.A. thesis, University of the Witwatersrand, 1984); Iris Berger, Threads of Solidarity: Women in South African Industry 1900-1980 (Bloomington, IN [etc.], I992).

26. Philip Bonner, "The Decline and Fall of the ICU: A Case of Self -Destruction", in Eddie Webster (ed.), Essays in Southern African Labour History (Johannesburg, 1978), pp. I I 4-I 20. 27. Helen Bradford, A Taste of Freedom: The ICU in Rural South Africa I924-30 (New Haven, CT [etc.], 1987). 
and I930s dominated Marion Lacey's influential Working for Boroko. ${ }^{28}$ Turning to labour in agriculture, one might single out the thesis of Mike Morris, yet another South African who studied in Britain, that pre-capitalist forms had virtually died out after the interwar years. ${ }^{29}$ This was hotly contested by others who brought out some of the complexity and variety of labour forms in farming, a debate especially accessible through the collection Putting a Plough to the Ground..$^{\circ}$

A series of important studies that went beyond episodic articles often focused on the strategic issues of the new labour movement that arose from the early i 970 s. Here one might start with the claim by David Hemson, in another often-used but never published doctoral thesis, that even migrant Durban dock workers, whose 1969 strike is often taken as the beginning of a new phase of contestation, the kick-off of the so-called Durban moment, could and would act as classic class-conscious proletarians. ${ }^{3 \mathrm{I}} \mathrm{A}$ number of influential studies were written on the development of these unions, with the hope that they would either form a new basis of resistance politics outside the ANC or that the alliance formed by the Confederation of South African Trade Unions (COSATU), established in 1985, with the ANC, would be powerfully influenced by COSATU. ${ }^{32}$ Gay Seidman particularly envisioned the new unions as potentially having a major influence on the formation of post-apartheid policies through bringing to bear comparison with the Workers' Party in Brazil. James Ferguson's remarkable study of the development industry, focused on the South African enclave of Lesotho, also advocated the delivery of this small enclave nation surrounded by South African territory from its inherent contradictory problems through incorporation into South Africa spearheaded by the NUM, the South African National Union of Mineworkers. ${ }^{33}$

Studies in this tradition have continued to be promoted in the Sociology of Work Programme at the University of the Witwatersrand and also

28. Marian Lacey, Working for Boroko: The Origins of a Labour System in South Africa (Johannesburg, I98 I).

29. Mike Morris, "The Development of Capitalism in Agriculture: Class Struggle in the South African Countryside", Economy and Society, 5 (1976), pp. 292-343.

30. William Beinart et al. (eds), Putting a Plough to the Ground: Accumulation and Dispossession in South Africa I850-1930 (Johannesburg, 1986).

3 I. David Hemson, "Class Consciousness and Migrant Workers: The Dock Workers of Durban” (Ph.D. thesis, University of Warwick, 1979).

32. Dennis MacShane et al., Power! Black Workers, their Union and the Struggle for Freedom in South Africa (Nottingham, 1984); Steven Friedman, Building Tomorrow Today: African Trade Unions 1970-84 (Johannesburg, 1987); Jeremy Baskin, Striking Back: A History of COSATU (Johannesburg, 199I); and Gay Seidman, Manufacturing Militance: Workers' Movements in Brazil and South Africa (Berkeley, CA [etc.], 1994). Interestingly, only the last of these was produced in a university context.

33. James Ferguson, The Anti-Politics Machine: 'Development', Depoliticisation and Political Power in Lesotho (Cape Town [etc.], 1990). 
through the History Workshop Project and the research chair led by historian Phil Bonner and now Noor Nieftagodien (with a parallel oral history project at the University of Cape Town). One should also note the presence in Newtown, Johannesburg of the Workers' Library and Museum in whose establishment History Workshop veterans played a central role. These continue to map out resistance politics, including the important labour component, particularly in the Johannesburg area and its Highveld hinterland. These references do not do justice to the range of publications that cover many parts of the country, different trades, episodes, and phases in which books must be joined by journal articles and many master's and doctoral theses (at the four English language universities that were designated for whites, especially the Universities of the Witwatersrand in Johannesburg and Cape Town, where radical ideas acquired growing legitimacy from the late I970s on).

However, while much of this literature gives great insight into actual workplace practices and conditions of work, studies which are not infused with the breath of anti-government and anti-apartheid politics are rare. A noteworthy exception of some importance but rarely imitation that stands out here in Jacklyn Cock's Maids and Madams. ${ }^{34}$ This book, whose content is pretty well explained by the title, explores a work relationship experienced by a very large number of South Africans, and which reveals a side of South African life of great importance, but it is rather unique. It is not that Cock was not an anti-apartheid activist, far from it, but her book looks directly at social contradictions difficult to express in conventional political terms. Her later investigations have moved from feminist issues to studies of the military and, more recently, to environmental criticism of development, subjects on which her work can be described as less lonely.

\section{LABOUR AND CULTURE}

In the last of his books that touches significantly on labour, Charles van Onselen produced a lengthy study of the life of a black sharecropper, originally modelled on a parallel project based in the US South. Van Onselen's Kas Maine was perhaps more of a small businessman and entrepreneur than a farm worker, although he certainly lifted his arm to the plough exhaustively in his heyday. At the end of his long life, he became dependent on exploiting the labour of his children, especially his daughters. The Seed is Mine is a quintessential South African story, rich in detail about farming on the South African Highveld and the social relations that prevailed on white-owned farms. ${ }^{35}$

34. Jacklyn Cock, Maids and Madams: A Study of Exploitation (Johannesburg, I980).

35. Charles van Onselen, The Seed is Mine: The Life of Kas Maine, a South African Sharecropper I894-1985 (Cape Town, 1994). 
The apartheid system and what preceded it are certainly illuminated in the book but it is not a history of resistance politics or organization in any sense.

This is also true of The Women of Phokeng, a study of working women on the Rand for whom paid labour and urban life represents a phase within longer strategic trajectories that take them back to their place of rural origin and do not define them. ${ }^{36}$ The author, Belinda Bozzoli, who wrote a classic article that first effectively pointed to the different experiences black women endured through proletarianization compared with men, is Van Onselen's wife and was Cock and Webster's colleague. ${ }^{37}$ A number of contemporary writers also interested themselves in understanding the black worker as a cultural innovator and actor. Ari Sitas, originally trained in Johannesburg, then a professor in Durban and finally Cape Town, promoted black worker theatre (Junction Avenue Theatre Company) and wrote about worker-poets while trying to grasp black workers as cultural activists. Luli Callinicos, active in the History Workshop movement in Johannesburg, produced and helped inspire several worker-orientated books replete with illustrations and aimed at a wider popular audience.

Some of this activity can simply be viewed as an extension of an intellectual project in full bloom. However, both The Seed is Mine and The Women of Phokeng, mark, I believe, the transition to another scholarly era which can be identified with the final end of apartheid, and both were influenced to an important extent by international currents of writing on labour and society. The "cultural turn" is already exposed in Harries's study of gold miners cited above and taken further by Moodie. Perhaps another unusual contribution that took the labour rhythms of African society, at the point where limited cash earnings were beginning to impact on Zulu households in the nineteenth century, as a subject for analysis almost unique for an historian, was the American Keletso Atkins's The Moon is Dead!, published just before the end of the old system. ${ }^{38}$ A Canadian-based student has recently returned to Hemson's dock workers to consider how militancy related to and spilt into petty entrepreneurship in part through illicit activity. ${ }^{39}$

36. Belinda Bozzoli, Women of Phokeng: Class, Life Strategies and Migrancy in South Africa 1900-83 (London, 1991). See also Deborah James, Songs of the Women Migrants (Edinburgh, 1999).

37. Belinda Bozzoli, "Marxism, Feminism and South African Studies", Journal of Southern African Studies, 9 (1983), pp. I39-17 I.

38. Keletso Atkins, The Moon is Dead! Give Us our Money!: The Cultural Origins of an African Work Ethic, Natal, South Africa, I843-1900 (Portsmouth, NH [etc.], 1993); idem, “Kafir Time': Preindustrial Temporal Concepts and Labour Discipline in Nineteenth Century Colonial Natal", Journal of African History, 29 (1989), pp. 229-244.

39. Ralph Callebert, "Working Class Action and Informal Trade on the Durban Docks, I930s-1950s", Journal of Southern African Studies, 38 (2012), pp. 847-862. 


\section{POST-APARTHEID SCHOLARSHIP}

If we consider contemporary labour studies, including historical work, two tendencies stand out. First, there is growing interest in studying problems related to labour, independent of the organizational issues focused on the rise of trade unions which will be discussed below. Second, given the political weight of the organized labour movement, there is a rather different literature considering the politics of labour and the prospects for what it called in South Africa the tripartite alliance - the African National Congress (ANC), the vastly less significant South African Communist Party, and COSATU which is the main trade-union federation. The former subject was not unexplored previously, but it was unfocused compared to the writing of history linked to unions and political parties, whereas it is now far more politically charged. The latter was almost irrelevant, although it is true that the white unions which organized workers who had the vote did play what might best be called the part of an interest group, an interest group of gradually declining weight. ${ }^{40}$ In both cases, I highlight a number of contemporary titles.

The importance of organized labour has been underestimated in African studies generally. The trade-union movement was not only a powerful element in the struggle against colonialism, this salience continued to be a factor afterwards. ${ }^{4 \mathrm{I}}$ Even in most African colonies where industrialization had not got far before the close of the colonial period, workers succeeded in organizing in sectors which were critical to the extractive economy that existed. This was especially true of miners, dock workers, railway workers, postal workers, and to a lesser extent other government workers. Big strikes convinced colonial authorities that to resist nationalist pressure would become increasingly costly, especially when trade unions were recognized as a potentially stabilizing feature, given the uneven and often harsh nature of the development process. However, as Cooper shows, transposing labour reforms familiar from European social discourse did not prove very effective on African terrain..$^{42}$

It is undoubtedly true in almost every case that, once in power, nationalist leaders had little use for autonomous union activity and generally tried to

40. Louwrens Pretorius, "Interaction between Interest Organisations and Government in South Africa”, Politieia, I (1982), pp. I-30. For a history of the trade-union movement to the present, see William Freund, "Organized Labor in the Republic of South Africa and Democratic Transition", in Jon Kraus (ed.), Trade Unions and the Coming of Democracy in Africa (London, 2007), pp. 199-228.

4I. This argument is developed as the main theme of Bill Freund, The African Worker (Cambridge 1988).

42. Frederick Cooper, Decolonisation and African Society: The Labor Question in French and British Africa (Cambridge, 1996). 
bring union movements under the wing of the state. However, this met with substantial resistance and, sooner or later, even in economically depressed conditions, an insurgent character returned to the unions. From around I980 onwards, the admittedly faltering turn towards liberal democracy, a process shepherded from the West but with substantial African roots in some cases, still often rested significantly on union support. ${ }^{43}$ Where to go from there has, however, been in question and in fact there is a remarkable spread of reactions as one looks through a variety of examples. This deviation is captured in a recent collection edited by Beckman et al. ${ }^{44}$

South African unions stand out in that they have neither been absorbed by the ANC nor have they sought a completely independent course. The organized workers' main federation has developed into a body that holds a sometimes uncomfortable and sometime cosy "alliance" with the ruling party. On the one hand, COSATU hopes to be a powerful influence politically and had an important part in the removal of President Thabo Mbeki and his replacement by Jacob Zuma in 2007. In recent years, big national strikes have won wage increases well above the inflation rate. However, on the other hand, it is sometimes unclear who gains from the alliance, apart from individuals who are able to use their union base to achieve prestigious positions through the ruling party in government. If beneficial legislation allows the unions to protect their members, does this not lead to a narrowing of outlook, despite the retention of a more ambitious rhetoric from past struggle days? These are the questions that Beckman et al. ask first and foremost. ${ }^{45}$

Furthermore COSATU has had only limited success in really changing the circumstances of the working world. Before the end of apartheid, the most militant COSATU workers were in mining, alongside metalworkers, and in other industrial sectors. Today, membership there has stagnated or declined, and government workers in the form of educational, health, and general municipal employees have become a very large proportion of the whole. The hardest-to-organize sectors, farm workers and domestic workers, not to speak of numerous African immigrants without permits, remain overwhelmingly unorganized. The turbulent democracy of shop and shaft stewards has given way to systematic national bargaining fora.

This paradox is well captured in the title and contents of a recent study by Sakhlela Buhlungu. ${ }^{46}$ Buhlungu stresses the decline of what he calls the struggle ethos as well as the loss of specialized expertise that gave COSATU some purchase on conceptualizing an altered society

43. Kraus, Trade Unions and the Coming of Democracy.

44. Bjørn Beckman et al., Trade Unions and Party Politics (Cape Town, 2010).

45. Ibid., p. I.

46. Sakhela Buhlungu, A Paradox of Victory: COSATU and the Democratic Transformation of South Africa (Pietermaritzburg, 2010). 
and economy. The alliance has yielded equivocal results. An example of success has been, for instance, pressure by the union and union researchers to save the railway parastatal rather than destroy it entirely. ${ }^{47}$ In the Mbeki years, tension between COSATU and the ANC mounted as the business world became prey to the internationalized pressures of globalization. It is true that the end of apartheid has led to improvements in the raw racial social order that dominated workplaces before and led to a far more centralized, anonymous and correct administrative praxis. However, the weight of international influence has blown in the direction of downsizing substantially the size of the industrial workforce and has militated against once promising corporatist initiatives in economic co-governance.

Moreover, the alliance traps the trade-union movement into impotence in many respects, while apparently giving the leadership, notably unlike ordinary membership in having become more male than in the past, influence and respect. In this way, relatively polite overtures from business towards union leadership to participate in cooperative structures usually leads to overwhelming pressure to conform to globalized structural changes - and, of course, business itself has come under often intense competitive pressures. Karl von Holdt demonstrates that point but also shows elsewhere the failure of unionization to create not merely a more humane order, but indeed any acceptable order, in a major South African health institution..$^{8}$

COSATU survives as an important factor in South African politics and economic considerations but certainly not as an emanation of the hopes of radical labour organizers of the late apartheid period. By contrast, the former Mine Workers' Union, once considered the bastion of white South African racism, has been surprisingly successful in re-inventing itself strategically, but minus the older leadership, as Solidarity, in some respects still militant but effective at representing the interests of skilled and supervisory workers. ${ }^{49}$

For Buhlungu, what he calls the "industrial union" model is beginning to show signs of irrelevance. This is what really emerges in a seminal, massive collection edited by Webster and von Holdt. They agree with

47. Karl von Holdt, “Saving Government from Itself', Trade Union Engagement with the Restructuring of Spoornet", in Edward Webster and Karl von Holdt (eds), Beyond the Apartheid Workplace (Pietermaritzburg, 2005), pp. 4I 3-434. The unions continue their involvement today in a stubborn and still unresolved movement to block the government from instituting tolls on the highways in Gauteng Province around Johannesburg and have been active in promoting the successful reduction of increases in electricity provision charges.

48. Karl von Holdt, "After Apartheid: Decay or Reconstruction in a Public Hospital?", in Webster and Von Holdt, Beyond the Apartheid Workplace (Pietermaritzburg, 2005), pp. $435-460$.

49. Wessel Visser, "From MWU to Solidarity:A Trade Union Reinventing Itself", South African Journal of Labour Relations, 30 (2006), pp. 19-4I. 
Buhlungu's claim that "a government vision of social dialogue, corporatist engagement and co-determination in the workplace" is a fantasy. ${ }^{50}$ Von Holdt, student of Webster and now successor to Webster and Buhlungu as director of the Sociology of Work Programme at the University of the Witwatersrand, has also produced a detailed and engaging history of the kind of changes Buhlungu considers in a major private steel mill in a provincial town. ${ }^{\text {I }}$ Von Holdt provides a memorable portrait of the apartheid workplace and the way racism and a very authoritarian system of command operated.

After the end of apartheid and the coming of the unions, management gradually and effectively turned towards "a programme to create a smaller, multi-skilled and flexible workforce that would simultaneously reduce costs and increase responsibility".52 This new order is much less ostensibly racist; depersonalized and deprived of any paternalistic element, it makes management remote and centralized in workers' eyes. Shop stewards are sometimes groomed to be promoted into supervisory positions. Where this system succeeds, the editors refer to "wildcat" bargains informally derived at shopfloor and firm level, quite independent of any broader union strategies. The collection contains other good examples of this kind of change, for instance in Bridget Kenny's chapter on life at the supermarket chain Shoprite, a workplace where unionization had made a big, positive difference following struggles. ${ }^{53}$ In effect, oppressive forms specific to the South African situation have given way to forms of labour control typical of so-called international best business practice that don't fit the traditional formulae. Many workers, some in unions and most not, are squeezed in a kind of race to the bottom. Thus, women are often more able to retain jobs in consumer industries but the character of the job is very unattractive, and the turn towards women is often tied to a form of deskilling. This emerges in discussions of clothing workshops in the Cape as well as shoemaking operations in Pietermaritzburg. ${ }^{54}$

This race to the bottom is poignantly illustrated in a recent and muchpublicized story splashing through the South African media. In Newcastle, which had been noted mainly due to its once state-owned steel mill, a

50. Webster and Von Holdt, Beyond the Apartheid Workplace, p. $2 \mathrm{I}$.

5. Karl von Holdt, Transition from Below: Forging Trade Unionism and Workplace Change in South Africa (Pietermaritzburg, 2003).

52. Webster and Von Holdt, Beyond the Apartheid Workplace, p. 68.

53. Bridget Kenny, “The 'Market Hegemonic Order' in Food Retailing”, in Webster and Von Holdt, Beyond the Apartheid Workplace, pp. 217-24I.

54. Sarah Mosoetsa, "The Consequences of South Africa's Economic Transition: The Remnants of the Footwear Industry", pp. 307-334; Christi van der Westhuizen, "Women and Work Restructuring in the Cape Town Clothing Industry", in Webster and Von Holdt, Beyond the Apartheid Workplace, pp. 335-356. 
significant clothing industry developed using black female labour, largely in the hands of (at first) Taiwanese and then, after the end of apartheid, mainland Chinese entrepreneurs. Today, the Chinese bosses demand that they be allowed to pay the workers below the very low minimum wage or else they will leave the area entirely. Unsurprisingly, the business press of South Africa has an unending stream of homilies on the sad fate of these factories due to government and union intransigence. A major court case brought by several Chinese businessmen is currently a media talking point, while some within the ANC are eager to allow for exemptions to the minimum wage structure that has been instituted and which these businessmen claim they cannot meet. There is no obvious escape from the horns of this dilemma.

Workers' experiences, despite some interesting individual cases that deviate from the norm, can be divided, Von Holdt and Webster argue, into three "zones".55 One is stable, secured work with a social wage, usually identified with trade-union membership and often state employment. The second zone is real enough as work - but precarious. Often workers are exploited through a loophole in legislation which defines them as individual contractors, no longer working directly for the employer engaged in some productive activity. These are the "the new working poor", ${ }^{6}$ with little in the way of a social wage. An important factor in their existence is the weakness of implementation of labour inspection. Third are the genuinely unemployed or underemployed in a country where no more than 60 per cent of the working-age population is actually employed, even counting the so-called informal sector. In other words, although work constitutes a shifting part of their lives, perhaps one-third or more of the adult population essentially survive from social grants and the earnings of those slightly less poor than themselves. ${ }^{57}$

However, it is also true that other workers are more secure and show higher satisfaction, especially but not only in the public sector. ${ }^{58}$ One approach to this story is to emphasize the emergence of layers of a minority of relatively successful and secure workers. For example, Böhm and Schirmer have depicted the emergence of a small stratum of skilled, better-paid farm workers in North West Province while the majority face marginalization and elimination. However, in response to minimum-wage

55. Webster and Von Holdt, Beyond the Apartheid Workplace.

56. Ibid., p.29.

57. Peter Alexander (ed.), Class in Soweto (Pietermaritzburg, forthcoming). By contrast with other parts of Africa and many other countries, in South Africa the dynamic of industrial capitalism has only permitted a very marginal and inconsequential, if fairly large, informal sector with a very limited productive sector. Surveys invariably report that workers in this sector would jump at the chance of earning a regular income in the formal sector if paid reasonably.

58. Alexander Beresford, "The Politics of Regenerative Nationalism in South Africa”, Journal of Southern African Studies, 34 (201 2), pp. 863-884. 
legislation, farm owners have got rid of the paternalistic services (free food, farm school support, free housing, lifts to the doctor) which once characterized farm life. ${ }^{59}$ Ironically, the bulk of the labour force miss racist paternalism! This irony is duplicated in a very different locale, the wine farms of the western Cape, ${ }^{60}$ where skilled workers are singled out from the "rural flotsam", to some extent defining a racial divide between Coloured and African at the same time. However, Phakathi simultaneously finds new lines of division amongst black workers in the depth of the mines as new forms of mechanization and computerization kick in. ${ }^{61}$ Buhlungu elsewhere quite specifically notes that workers of the postapartheid generation, while the average worker in the union gets older, are notably more individualistic and acquisitive in the sense of goals: they no longer envision an idealized common future. ${ }^{62}$

However, a second approach to be delineated which perhaps requires, as Webster and Von Holdt put it, that "we have to reconceptualise the meaning of work", ${ }^{63}$ is to question the whole nature of work and its impact on society. This school not only enriches and modifies our sense of the organized and statutory body of employees, but approaches labour completely autonomously. Yet another contributor to Von Holdt and Webster's book, David Masondo, considers that even the very paragons of "decent work"(to take the COSATU adage now utilized systematically by the government as well), the well-paid employees of the luxury German car firms operating in the eastern Cape, are leading a life weighed down, first by demands that they support a large number of conventional dependents; second, by the work experience, including the racial lines that mark South African society, which hasn't really altered; and third, by alcohol and high measures of indebtedness, besieged by the prevalence of AIDs and high crime rates. Substantial savings and long-term life planning are only possible on paper. ${ }^{64}$ This means that the social wage itself is often willingly

59. Astrid Böhm and Stefan Schirmer, "Development by Decree: The Impact of Minimum Wage Legislation on a Farming Area in North West Province", in Bill Freund and Harald Witt (eds), Development Dilemmas in Post: Apartheid South Africa (Pietermaritzburg, 2010), pp. 248-274. See also Gilton Klerck and Lalitha Naidoo, "Minimum Wages for Farm Workers", in Greg Ruiters (ed.), The Fate of the Eastern Cape: History, Politics and Social Policy (Pietermaritzburg, 201 I), pp. 300-309.

60. Joachim Ewart and Andries du Toit, "New Fault Lines in the Countryside: Restructuring in the Western Cape Wine Industry", in Webster and Von Holdt, Beyond the Apartheid Workplace, pp. $45-72$.

6r. Timothy Sizwe Phakhati, "Self-Directed Work Teams in a Post-Apartheid Gold Mine: Perspectives from the Rockface", in Webster and Von Holdt, Beyond the Apartheid Workplace, pp. 173-1 86.

62. Buhlungu, A Paradox of Victory.

63. Webster and Von Holdt, Beyond the Apartheid Workplace, p. $3^{8 .}$

64. David Masondo, "Trade Liberalisation and Work Restructuring in Post-Apartheid South Africa: A Case Study of BMW", in Webster and Von Holdt, Beyond the Apartheid Workplace, pp. 149-172. 
traded in for more cash. Moreover, in the face of these conditions, transformation has not convincingly arrived in the schemes of post-apartheid management. The "lofty ideals often found in the wording of policy guidelines are notoriously difficult to translate into workable practice". ${ }^{65}$

\section{MARIKANA AND AFTER}

If we consider very recent articles on the Marikana crisis that is further discussed below, the descriptive notes on the lives of mine employees are consistently illustrative of this situation:

Anele is a Lonmin winch operatior in his early $30 \mathrm{~s}$, the only breadwinner for a family of five, taking home $\mathrm{R}_{4}, 100$ a month after deductions. His wife and children stay in the Eastern Cape $[\ldots]$ now he shares a tiny shack $[\ldots]$ with his brother, who came to live with him a year ago. The four families in his year share one toilet, and there is no running water. There's just enough room for a fridge, a bed and a broken television set in his shack but some of the housing allowance can now be diverted to feed hungry mouths at home. [...Lucky] made $R_{4}, 000$ a month after deductions, which wasn't enough to sustain his mother and brother in Gauteng [the province around Johannesburg], his girlfriend and his baby [...].They share a toilet with eight other families. He's 27 [...]. You cannot build a home on R6,000 a month. [...] although the workers got R 9,000 in the end, after deductions of ${ }_{4} \%$ for tax, and then more for the provident fund and medical aid, they'll end up getting about R6,000, which is close to what they earned before [...]. Joseph [...] has four sisters, two of whom are street vendors and the others unemployed. His girlfriend works in a shop and they struggle to feed their three kids by the end of the month [...]. Michael Moseki, an elected strike leader [...] talks about the challenges of raising his five children on $\mathrm{R}_{4,700}$ a month [..]. His three older children live with his mother near Bloemfontein in the Free State province. "I don't always have money to give to my mother [...]. My wife doesn't work [...]. Tebogo [...] get[s] 6.2 (R6,200). They didn't tell me it was going to be a demotion. I have a sister who is studying nursing on my salary, which is $R_{3}, 000$ every month. I pay $R 600$ for my rent, food for myself and for my mother and two sisters and my brother who is in grade 2. None of them work [...]. Nomfulela's husband [...] has spent I 2 hours underground chasing a meagre bonus with a $75 \mathrm{~kg}$ machine in hand. Before the Lonmin strike he was making $R_{3,500}$ a month. Nomfulela is 46 years old and together they have three children. She's been unemployed ever since she got to Marikana in I 993 when she came fearlessly from KZN [the province of KwaZulu-Natal] looking for greener pastures. She now survives through the child income grant. They live in a tiny shack in Nkaneng. ${ }^{66}$

The wages are in real, not just relative, terms much better than under apartheid. The unionized workers are covered by bargained contracts that

65. Phakhati, "Self-Directed Work Teams", pp. I73-186, i8 5.

66. Amandla, 28/29 December 20I2, pp. 2I-32. 
offer them medical insurance and provident fund payments as a chosen alternative to a pension. A housing allowance is also provided in lieu of access to reasonably kept hostel accommodation, but this allowance is suitable for a single individual, and workers prefer to house family and dependents in the cheapest alternative housing and send more money out to yet others in different parts of the country. They are reasonably paid workers (typically heavily in usurious debt) - they also often receive bonuses when mineral prices are good - who live in a sea of poor people, notably women, who have no source of income and search for protectors for themselves and their children. There is little gap here between the working class and the immense so-called lumpenproletariat whose lives are intertwined. The numbers involved and the course of economic growth thus far make it difficult to see this in terms of a reserve army of labour where the demand for unskilled labour has shrunk so markedly. In I97I, South African employment figures jointly in manufacturing, mining, and agriculture were considerably larger than today for a population one-third today's size. Many of the workers now have not merely primary but even secondary education but the quality of the schools they attend does not really provide them with any practical skills.

To a limited extent, the grudging concessions apartheid made to the necessity of accommodating a black working class in South Africa, did allow a minority of black men and women to create a family and home life that was not entirely lacking, despite poverty and exclusion. Some of the most thoughtful and disturbing recent literature puts the blame for extremely anti-social living conditions on the decay of this possibility and the vulnerability of black men to dismissal and marginalization, in particular through the close study of small communities. ${ }^{67}$ Indeed gender becomes a crucial lens with which to view worker life on and off the job. Hunter explores exploitative gender relations intensively while Niehaus takes on the truly black box of child rape and child rape accusations. The much more open climate for behaviour seen as overly permissive and deviant plays a role here too, especially in the behaviour of men socialized with patriarchal assumptions. In Hunter's study of a small town in Zululand, women have become far more vulnerable with the closing of factories, while Niehaus explores the reverse situation where women, rather than men, have been able quite often to retain jobs.

Another interesting recent voice is that of Franco Barchiesi, inflected with recent European theory (Deleuze and Guattari, Castoriades, Gorz, Negri and Hardt, Agamben) critiquing the conventional foundations of Journal of Southern African Studies, 36 (2010), pp. 833-850. 
social democracy. ${ }^{68}$ Barchiesi, focusing on male municipal and industrial workers on the east Rand, like Masondo finds that, if wages have risen, so intensive new demands have emerged to pay for electricity, water, and the like, while access to genuinely better housing remains a bridge too far. Moreover, men in work feel the precariousness of a situation where so many have lost jobs or been rendered contract or part-time workers. Again, having to dispense with pension and health benefits for immediate cash as well as falling into debt are the fate of the apparently better-off, and the shift to contract employment is thus sometimes actually welcomed, so strong is the compelling short-term argument. Barchiesi has perhaps exaggerated both the lack of achievement of the union movement and the extent to which COSATU and the ANC have preached a false paradise, whereby liberation will come through and be accompanied with idealized conditions of work, although he can certainly find statements to back up the latter. The ANC has perhaps always put more emphasis on the possibilities of social mobility rather than a solidifying working class, and emphasized the idea that only the iron curtain of racism prevented blacks from experiencing the good life. It has simply never evolved or adopted a systematic social democratic conception of governance tied to bringing the working class up as a class.

The real problem is the failure of either organization (or indeed the Communist Party) to elaborate on or diffuse a vision of a non-racial social democracy which inevitably would have to go far beyond the workplace at any point. The way in which socialism flowed out of trade unionism historically in Europe, or helped in some cases rather to shape $i t$, is a dramatic contrast. In its heyday it was to some extent scientific, not utopian, to paraphrase Engels. This vision is eloquently held out by that great labour fellow-traveller, Eddie Webster, in a valedictory article on his retirement. ${ }^{69}$ However, it can be argued that far from being a struggle "for the right to work", ${ }^{70}$ by and large under apartheid labour militancy was often a struggle resisting unwanted and oppressive work. In this sense, socialism never captured - except very superficially - working-class consciousness in South Africa. With the onset of globalization as well, the struggle for what Webster, and COSATU, call "decent work", goes right against the flow of the stream, and it is difficult entirely to dismiss Barchiesi's attempt to diminish its centrality, certainly to a socialist project of the future.

68. Franco Barchiesi, Precarious Liberation: Workers, the State and Contested Social Citizenship in Post-Apartheid South Africa (Albany, NY [etc.], 201 I).

69. Edward Webster, “There Shall be Work and Security', Utopian Thinking or a Necessary Condition for Development and Social Cohesion", Transformation, 72/73 (2010), pp. $225-246$. 70. Ibid., p. 225. 
I have written elsewhere of a way of looking at the present regime in South Africa as a stable one. ${ }^{71} \mathrm{~A}$ few become very rich; a large minority is "empowered" and have entered the middle class, albeit mostly dependent on state employment; a still larger minority benefits from union recognition and the diffusion of a modern infrastructure to serve the whole population, despite the limitations outlined above; while the largest group of all at least receive the social-grant trio - pensions for all, child support grants, and disability grants. The white minority may find the system distasteful but they have no real way of contesting it democratically and opposition politics is limited to a bounded constituency. The ANC has approximately three times the vote of the largest opposition group, which has very marginal black support, enjoying an overwhelming - and even increasing - percentage of the vote of the racially defined black majority.

However, as the liberation ethos runs out of steam and ideas, there is no lack of discontent. One form is identifiable: frequent massive national strikes in key sectors that force settlements beyond the official inflation rate or what capital and the state were initially prepared to offer. Largescale action in the platinum mines but spreading into other sectors completely independent of the activities of the NUM, and at a moment when industrial trade is stagnating internationally after a boom period, is a dramatic example which has led to violent conflict between strikers and police at the now notorious Marikana mine camp. In August 20I2, thirty-four miners died when a mass meeting was forcibly broken up after a series of violent incidents which also resulted in the brutal deaths of policemen. ${ }^{2}$

The Marikana story, which made world headlines, has various angles, notably the behaviour of a police force following orders difficult to defend. However, another element is the naked alliance between the mine

7I. Bill Freund, "South Africa as a Developmental State? Changes in the Social Structure since the End of Apartheid and the Emergence of the BEE Elite", Review of African Political Economy, II4 (2007), pp. 66I-678.

72. Peter Alexander et al., Marikana: A View from the Mountain and a Case to Answer (Johannesburg, 20I2). See also the excellent account by Gavin Hartford, a former trade unionist, in the Weekly Mail and Guardian, I2 October 20I 2. For background to Marikana with reference to the development of the platinum industry, which has in recent years become South Africa's most valuable export, see Gavin Capps, "A Bourgeois Reform with Social Justice? The Contradictions of the Minerals Development Bill and Black Economic Empowerment in the South African Platinum Mining Industry", Review of African Political Economy, 39 (2012), pp. 315-334. For background with reference to the situation of rock drillers, the mine face workers who are now placed lower down the salary scale as formal education and skill become more valued, see Paul Stewart, "Labour Time on the South African Gold Mines I886-2006" (Ph.D thesis, University of the Witwatersrand, 2006). Alexander has also done an important study of the history of the Transvaal coal mine workers: Peter Alexander, "Oscillating Migrants, 'Detribalised Miners' and Militancy; Mozambicans on Witbank Collieries 1918-27”, Journal of Southern African Studies, 27 (200I), pp. 505-526. 
management, sensitive to the oscillating world price of platinum, the state in charge of policing, and the NUM, which had already been challenged by a rival apolitical union, but which stood by its bargained contracts. For the purposes of this paper, the most striking point has been the failure of what would ostensibly be considered a democratically conceived and respectable set of wage agreements via collective bargaining. Workers, alienated from the NUM and its bureaucratic structures, often see the union as having evolved into a kind of substitute for the apartheid-era bossboy intermediaries and refuse to accept their negotiated wages. The part of their pay distinct from the take-home cash is not much valued and the union no longer links workers and their felt needs to the bargaining table in reality.

They listened with some alacrity to the racist demagogue Julius Malema, now disgraced in the ANC, who claimed he wanted to take over all the property of the amabhunu (a pejorative term for whites). The demand is not for another politics but for force, if need be through violent action, the ANC party-state to decree higher wages, turning an improved paper wage into the desired take-home cash. Indeed in response, pressures obliged the employer to offer considerably higher pay packets and the ANC reacted as strongly as it could when platinum companies began to lay off thousands of workers. Another recent flare up on the farms of the western Cape has now led to the government feeling obliged to raise the minimum wage. However, there will be no guarantees that jobs will be retained, and indeed some small town ANC municipal councillors are apparently doubling as labour contractors.

A second series of insurgencies has consisted of protests over "service delivery", mainly electricity, water, and houses, often tied to the sins of corrupt and idle local officials who are both very widely found but are challenged by ambitious political rivals within the ANC. These protests in style and method are tied to the anti-apartheid tradition and aimed at getting the attention of the ruling party, even though they have led to such violent confrontations from time to time that there are even deaths. The state reacts with rage at being challenged, can be quite heavy-handed, but again often ends by making concessions. ${ }^{73}$ They are, however, by definition localized, often defensive, and not likely to bring forth an alternative politics, formal or informal. ${ }^{74}$

73. Marikana too led to significant wage concessions, although struggles elsewhere are still unresolved.

74. Richard Ballard et al. (eds), Voices of Protest: Social Movements in Post-Apartheid South Africa (Pietermaritzburg, 2006); David McDonald (ed.), Electric Capitalism (Sterling, VA, 2007); David McDonald and Greg Ruiters (eds), The Age of Commodity (Sterling, VA, 2005); Buntu Siwisa, "Social Citizenship and the Emergence of the New Social Movements in PostApartheid South Africa", in Freund and Witt, Development Dilemmas, pp. 195-2 I 8. 
Recent local elections suggest some desertion of the ruling party by the black middle class, holding its nose at the spectre of Malema, and indeed President Zuma. It hankers for the Mbeki era. However, this class is too small and too marginal to the productive system to take charge (yet) and Zuma is clearly eager to meet some of their demands for a business-like state and to prevent the ANC descending into a set of corrupt factions. By contrast, systematic research shows that the poorer the locale and the greater the absence of any opposition, the greater the likelihood of a large voter turnout as a hopeful gesture of affirmation. Some day the ANC may split, but it is more likely to be a result of intensifying factionalism than due to any ideological rift. However, Beresford suggests plausibly, based on the Malema episode and the enthusiastic support this talented demagogic speaker and impressive youthful money-maker received from his base in the party Youth League, that a more narrowly Africanist agenda might well succeed one day in transforming, or perhaps in the wake of a seriously damaging factional split, conjuring up a rival to the ANC. ${ }^{75}$ The atmosphere in recent years leads legitimately to less certainty concerning stability than in previous writing. Labour in South Africa has been conceptualized forcefully and powerfully in the past half-century through the lens of politics and it is likely that as new analytical and historic trends emerge, this will continue to be the case.

\author{
TRANSLATED ABSTRACTS \\ FRENCH - GERMAN - SPANISH
}

Bill Freund. Études sociales et histoire sociale en Afrique du Sud: perspectives de l'ère de l'apartheid et ensuite.

Cet article tente d'introduire les lecteurs à l'impressionnante et influente littérature historique et contemporaine sur les travailleurs sud-africains. Une littérature évoquant certains aspects antérieurs appliqua avec efficacité des thèmes sociologiques et historiques classiques aux conditions particulières de l'évolution politique et économique sud-africaine. La recherche sur la phase de l'action du travailleur blanc politisé et militant se rattache à celle sur le mouvement ouvrier international avant la Première Guerre mondiale. La force de cette littérature refléta le mouvement ouvrier insurgé rejoignant la lutte politique contre l'apartheid avant 1990. Après cette étude, la deuxième moitié de l'article tente de considérer et de contextualiser la difficile situation ouvrière et ses aspects politiques. Lors de la conclusion et victoire de la lutte anti-apartheid, les étudiants du mouvement ouvrier et la société sud-africaine prirent plus conscience de l'écart entre l'instauration d'une démocratie libérale et la transformation de la société même

75. Beresford, "Politics of Regenerative Nationalism". Communist Party leader Jeremy Cronin called this tendency Zanufication, and indeed the parallels with Zimbabwe are striking. Malema is a keen admirer of Zimbabwean President Robert Mugabe and his thuggish supporters. 
dans le sens d'une réduction des inégalités et d'une amélioration des conditions de vie pour les couches sociales inférieures ou même la grande masse de la population. Comme le montre la littérature récente, l'évolution de l'Afrique du Sud postapartheid fut une expérience différenciée et problématique pour les travailleurs.

\section{Traduction: Christine Krätke-Plard}

Bill Freund. Arbeitsforschung und Arbeitsgeschichte in Südafrika: Perspektiven aus und seit der Apartheidzeit.

Dieser Aufsatz bemüht sich, die Leser in die eindrucksvolle und einflussreiche historische und aktuelle Literatur zur Arbeit in Südafrika einzuführen, eine Literatur mit einigen Vorläufern, die klassische soziologische und historische Themen effektiv auf die besonderen Bedingungen der politischen und wirtschaftlichen Entwicklung Südafrikas angewandt hat. Forschungen zur Phase der Aktivitäten politisierter und militanter weißer Arbeiter verbinden sich mit Forschungen zur internationalen Arbeiterbewegung vor dem Ersten Weltkrieg. Die Stärke dieser Literatur spiegelt die rebellische Arbeiterbewegung, die mit dem politischen Kampf gegen die Apartheid vor 1990 assoziiert war. Nach diesem Überblick werden in der zweiten Hälfte des Aufsatzes die schwierige Arbeitssituation seit dem Ende der Apartheid und die politischen Aspekte dieser Situation betrachtet und kontextualisiert. Seit dem erfolgreichen Ausgang des Kampfes gegen die Apartheid sind sich Forscher, die sich mit der Arbeiterbewegung und mit der südafrikanischen Gesellschaft befassen, deutlicher der Kluft bewusst geworden, die zwischen der Einrichtung einer liberalen Demokratie und der tatsächlichen Veränderung der Gesellschaft liegt, einer Veränderung, die zu weniger Ungleichheit und einem besseren Leben für die untersten Schichten der Gesellschaft oder sogar die breite Masse der Bevölkerung führt. Die Entwicklung Südafrikas seit der Apartheid ist, wie die neuere Literatur zeigt, für Arbeiter und Arbeiterinnen eine vielschichtige und problematische Erfahrung gewesen.

Übersetzung: Max Henninger

Bill Freund. Estudios del trabajo e Historia del trabajo en Sudáfrica: Perspectivas desde la era del apartheid y los años posteriores.

Este artículo es un intento de dar a conocer a los lectores la impresionante e influyente literatura histórica y contemporánea dedicada al mundo del trabajo en Sudáfrica. Una literatura en la que algunos de sus antecedentes más tempranos son ejemplo de una aplicación efectiva de la sociología clásica y de los temas históricos a las condiciones específicas del desarrollo político y económico de Sudáfrica. La investigación sobre la fase de las acciones de los trabajadores blancos politizados y militantes se enlaza con las investigaciones del movimiento obre internacional anterior a la Primera Guerra Mundial. Lo más destacado de toda esta literatura reflejaba un movimiento obrero insurgente vinculado a las luchas políticas contra el apartheid antes de 1990. Después de esta revisión, la segunda parte de nuestro artículo trata de considerar y contextualizar los retos de la situación laboral de la 
época posterior al apartheid junto con sus aspectos políticos. Con la exitosa consecución de la lucha contra el sistema del apartheid, los estudiosos del movimiento obrero, tanto como los estudiosos de la sociedad sudafricana, han llegado a ser mucho más cuidadosos respecto a la distancia que existe entre el establecimiento de una democracia liberal y los cambios actuales de la misma sociedad en una dirección que conduce a plantear los efectos sobre una menor desigualdad y unas mejores condiciones de vida para aquellos que se sitúan en los estratos sociales inferiores; lo que incluso podríamos llegar a extender a la mayor parte de la población. Como ponen de relieve los estudios más recientes, el desarrollo de Sudáfrica tras el apartheid ha sido una experiencia diferencial y problemática para el mundo del trabajo.

Traducción: Vicent Sanz Rozalén 